\title{
The Effect of Colostomy and Ileostomy on Acts of Worship in the Islamic Faith
}

Betül AKGÜL, MsN, Nurse, Türkiye Yüksek Ihtisas Hospital, Sihhiye/Ankara, Turkey EMail: btkalkan@hotmail.com

Ayişe KARADAĞ, MsN ; PhD, ET/WOCN, Prof. Dr., Koç University School of Nursing, Istanbul, Turkey E-Mail: ayisekaradag@ gmail.com; akaradag@ ku.edu.tr 
Purpose: The aim of this study is to determine the impact of colostomy and ileostomy on Muslim patients' acts of worship.

Design: Cross-sectional, descriptive study.

Subjects and Setting: The research setting was a stoma therapy unit of a 500-bed capacity training and research hospital in Ankara, Turkey. The study sample comprised 150 patients with colostomies $(40.7 \%)$ or ileostomies (59.3\%); their mean age was $51.6 \pm 12.9$ (mean \pm SD), more than half $(60.7 \%)$ were men, and $84.7 \%$ were married.

Methods: Participants were queried about specific religious practices following ostomy surgery including those related to salat, fasting and pilgrimage. Data were collected using forms specifically designed for this study; respondents were interviewed either face-to-face or via telephone. Descriptive statistics were used to characterize the influence of a fecal ostomy on specific religious activities. Results: Participants reported decreasing the frequency of daily and Friday prayers $(25.2 \%$ and $22.7 \%$, respectively) or stop practicing these activities all together (12.0\% and $14.0 \%$, respectively). Respondents tended to increase the frequency of acts of absolution while reducing acts of fasting. Perceptions of cleanliness, central to performance of salat within the Islamic faith emerged as a central concern. Conclusions: Ostomy surgery influences multiple religious acts practiced by Muslims. Awareness of the potential impact of a fecal ostomy on religious acts within the Islamic faith, combined with specialized education about spiritual practices delivered by the WOC nurse or a knowledgeable resource person is strongly recommended for all persons following ostomy surgery. 


\section{Introduction}

Creation of a fecal ostomy (ileostomy or colostomy) influences multiple dimensions of health related quality of life (HRQOL), including body image, self-esteem, social, recreational activities, and relationships with friends and family. ${ }^{7-9}$ A stoma also may influence spiritual and religious activities. One of the religious groups most affected by a stoma are Muslims. The worship rituals of Islam are rigidly defined. Acceptance of a stoma within the Islamic culture is challenging owing to 2 main factors: 1.) the high value placed on privacy in relationship to bowel and bladder elimination, and 2.) the belief that the involuntary flatulence and excretion of fecal effluent via the ostomy renders certain acts of worship invalid. ${ }^{10-13}$

There are 5 major expressions of an individual's Muslim faith, performing the salat, fasting, giving alms, expressing testimony, and going on pilgrimage to Mecca. ${ }^{14}$ Salat, fasting and going on pilgrimage are especially likely to be negatively affected by an ostomy. Fasting is an act of worship which starts by expressing the intention to fast at early dawn (sunrise); it requires total avoidance of food, drink, and sexual acts until sunset, a period of as long as 16 hours. ${ }^{15}$ Fasting may lead to liquid electrolyte imbalances in ileostomy patients and constipation in those with colostomies. ${ }^{16}$ Limited evidence suggests that Muslim persons tend to interfere with performance of the salat, whether it is practiced at home or with a congregation in the mosque. ${ }^{10,17,18}$

Muslims perform the salat 5 times daily. The salat is an act of religious worship that is accompanied with special bodily movements and prayers. For the salat to be valid, the worshiper's body and clothes, and the place where the salat is performed must be clean. Before the salat, worshippers perform ablution. Islamic law defines ablution as washing some body parts duly with water (like the face, hands, and feet) and wiping over some other parts with hands wet with water (neck, lower arms). Ablution is mandatory to perform prayer, to circumambulate the Kaaba, to perform recitation prostration, and to touch the Quran. Contact 
with bodily effluents, including feces, flatus, stool, semen, or blood invalidates the cleanliness required when performing the salat. ${ }^{14,15}$ The Turkish Directorate of Religious Affairs has declared that having a stoma does not prevent ablution and prayer, and gas or excrement discharge into an ostomy pouch does not invalidate worship. Nevertheless, research reveals that many Muslims living with an ostomy find that discharge from a fecal ostomy interferes with their perceptions of achieving adequate cleanliness prior to performance of their salat. ${ }^{18}$ For example, a study of men with fecal ostomies found that passage of flatus or discharge of effluent into the ostomy pouch (common when worshipping in the knee-elbow position) was the primary reason for avoiding attendance at Friday prayers, and other researchers have observed that passage of audible flatus or odor from the ostomy pouch is likely to prevent men from performing acts of worship with a congregation ${ }^{19-22}$. Separation from their congregation may lead to withdrawal and avoidance behavior, and deterioration in interpersonal relationships and overall quality of life. ${ }^{23}$

Another Muslim act of worship negatively affected by a stoma is the pilgrimage to Mecca or Hac. The Islamic term Hac is defined as visiting the Kaaba in the city of Mecca and other places in the surrounding area that are considered holy. Such a visit occurs within a circumscribed time frame and must be accompanied by completion of specific rituals and ceremonies. $^{24,25}$ Clearly, WOC nurses should have knowledge of the potential impact of a fecal or urinary ostomy on the religious acts of Muslim patients. The aim of the study was to investigate the effect of a colostomy or ileostomy on Muslim patients' worship acts and habits.

\section{Methods}

A cross-sectional, descriptive design guided data collection and analysis. The study was conducted in adult patients cared for in the Stoma Therapy Unit of a 500-bed training and research hospital in Ankara, Turkey. The stoma unit was established in 2007 and is the only 
public hospital unit in Ankara dedicated to care of persons with ostomies; 2 certified woundostomy care nurses are based on this unit.

The target population comprised 655 adults with fecal ostomies who received services from the Stoma Therapy Unit in Ankara; 473 of the ostomies were classified as temporary and 182 permanent. The study sample comprised those patients seen in the unit between October 1 and December 31, 2012. Inclusion criteria were: having an ostomy for at least 2 months, $\geq 18$ years of age, and able to provide answers to data collectors. Study procedures were reviewed and approved by the Ethics Board of the Türkiye Yüksek Ihtisas Hospital, Ankara. Patients were informed about the study and their oral consent to participate was obtained.

\section{Study Procedures}

Data were collected between October 1 and December 31, 2012 using 2 forms, a patient characteristic form and a worship evaluation form. The patient characteristic form queried socio-demographic features ( 9 items) and stoma related characteristics ( 9 items). The worship evaluation form comprised 15 items that queried performance of salat (6 items), ablution (3 items), fasting ( 3 items), pilgrimage ( 3 items) and 1 item related to provision of worship related training in the post-operative period.

The forms used to collect data were designed for the study. In order to evaluate the content validity and feasibility of these forms, we conducted a pilot study with 10 persons with ostomies cared for in a stoma therapy unit of a different university hospital, Ankara. Minor changes were made after pilot test. Data collection forms were administered to patients by the researcher. The researcher introduced herself, explained the purpose of the study, and completed the questionnaires during a verbal interaction carried out via a face-to-face $(n=58)$ or telephone interview $(\mathrm{n}=92)$.

\section{Data Analysis}


Data were analyzed via SPSS (Statistical Package for the Social Sciences, Chicago IL) software program version 20. Descriptive statistics were used to analyze outcomes of this descriptive study.

\section{Results}

The study sample comprised 150 patients cared for in our Stoma Therapy Unit. Demographic characteristics of participants are summarized in Table 1. Their mean age was $51.6 \pm 12.9($ mean $\pm \mathrm{SD})$, more than half $(60.7 \%)$ were men, $84.7 \%$ were married, and $2.7 \%$ stated they lived alone. Slightly more than one-third (36.0\%) were retired. Of the participants, 36.7\% have low income $(739,80 \downarrow-919,48 \downarrow)$ and $10.0 \%$ have an upper range incomes (2.995.040 t or higher

Just under half of participants $(46.7 \%)$ underwent ostomy surgery to manage colorectal cancer, and 59.3\% underwent creation of an ileostomy. More than half of the ostomies in our sample $(58.7 \%)$ were classified as temporary, and $65.3 \%$ reported living with a stoma for 3 to12 months. The majority of participants (61.3\%) reported receiving worshiprelated education following ostomy surgery. Most stated they were trained by a WOC nurse (94.5\%), and $88.0 \%$ found the training sufficient.

Table 3 summarizes the impact of an ostomy on performance of acts related to salat. Thirty six percent stated daily performance of salat had not changed after ostomy surgery, $22.7 \%$ stated that their performance of salat had decreased; $14.0 \%$ had stopped performing the salat completely; and $2.0 \%$ said they had started to perform the daily salat at home. Slightly more than half of respondents $(50.8 \%)$ reported no change in participation in Friday prayers in the mosque, and $25.2 \%$ stated they reduces participation in Friday prayers after surgery. The vast majority (78.9\%) stated that passage of flatus or fecal effluent into their ostomy pouch did not exert a negative effect on the validity of their salat. Table 4 presents findings related to patients' performing ablution after ostomy surgery. Slightly less than half 
of respondents (48.0\%) reported an increase performance of ablution, and $93.0 \%$ stated they consistently required ablution before performing their salat. Nevertheless, $20.7 \%$ stated they did not feel sufficiently clean prior to starting the salat, and $21.3 \%$ reported that they considered ablution to be invalidated if gas or feces discharge from their stoma during performance of their salat.

Table 5 summarizes the influence of ostomy creation on fasting and pilgrimage related activities. Although $76.0 \%$ of participants stated they fasted every year before ostomy surgery, only $8.0 \%$ continued after creation of a stoma. The majority of respondents $(72.7 \%)$ stated they did not find living with an ostomy acted as a barrier to going on pilgrimage. Concerns related to pilgrimage included difficulty performing ablution at each salat time, and fear of ostomy pouch leakage and subsequent inability to engage in worship.

\section{Discussion}

We found that ostomy surgery creates challenges for multiple religious practices within the Islamic faith including those related to ablution and performance of the salat, fasting, and pilgrimage. More than half of participants reported an increased number of ablution (cleansing) activities after ostomy surgery, and 93.0\% stated that they performed ablution before each salat. Despite a directive from the Turkish Directorate of Religious Affairs, $20.7 \%$ of respondents stated they did not feel clean enough when beginning the salat and $21.3 \%$ indicated a persistent belief that a discharge of gas or fecal effluent invalidates their ablution (Table 4).

Persons practicing the Islamic faith use the term "excuse" top describe any condition present at salat time that invalidates ablution. ${ }^{30} \mathrm{~A}$ worshipper with a excuse must perform ablution at each salat time for as long as the excuse lasts. Following successful ablution the worshipper can perform as many salat acts as he or she wishes. ${ }^{14}$ We found that while participants tended to perform more ablutions following ostomy surgery, they also tended to 
continue daily salat that we attribute to the specific education focusing on acts of worship within the Muslim faith following ostomy surgery. The strength of this conclusion is strengthened by the findings of Hussein and Fadl' $1 \mathrm{n}^{22}$ who conducted a study with 28 persons with ostomies and reported that only $58.3 \%$ performed a single ablution before engaging in salat, and $37.5 \%$ described the need to empty their ostomy pouches several times before achieving ablution.

The advantages of specific education are also reflected in the findings of Çavdar and colleagues ${ }^{14}$ who evaluated 66 persons with ostomies at 3 facilities without a WOC nurse. They reported that their participants reported inadequate information about their religious practices and expressed a desire for additional counseling in this area. Similarly, Khan and colleagues $^{20}$ investigated health related quality of 100 Muslims with ostomies who received specialized training after surgery. Contrary to the researchers' expectation, they found that participants had higher scores on spiritual life when compared to other HRQOL domains.

We found that the most significant changes in faith-based acts following ostomy surgery related to annual fasting, which declined from $76.0 \%$ to $8.0 \%$. In addition we found patients in the nonfasting group had significantly higher albumin levels $(4,15 \pm 0,49$ versus $3,27 \pm 0,25, \mathrm{p}=0,001)$ than patients in the fasting group. Similarly, Çavdar and colleagues ${ }^{17}$ reorted that $87.9 \%$ of their subjects fasted regularly before ostomy surgery as compared to $43.9 \%$ after surgery. In contrast, Altuntaş and colleagues ${ }^{31}$ evaluated the impact of fasting on 14 subjects who fasted during Ramadan as compared to 42 participants who did not. They found no negative nutritional outcomes apart from a decrease in serum prealbumin. They found patients in the fasting group had significantly higher albumin levels $(4.6 \pm 0.2$ versus $4.1 \pm 0.4, \mathrm{P}=0.001)$, prealbumin levels $(27.6 \pm 7.4$ versus $21.3 \pm 8.5, \mathrm{P}=0.018)$ than patients in the nonfasting group. However, the number of persons who completed fasting was small $(n=14)$ and only 6 had ileostomies. Our clinical experience suggests that fasting is particularly 
challenging for patients with an ileostomy. Additional research is needed to evaluate the impact of fasting on persons with fecal ostomies, and particularly those with ileostomies.

We found that $27.3 \%$ of patients indicated that the presence of a fecal ostomy acts as an obstacle to pilgrimage. When queried about characteristics of this belief, they identified difficulties performing ablution during pilgrimage and anxiety of pouch leakage during acts of salat. Our findings are similar to those of Hussein and $\mathrm{Fadl}^{22}(\mathrm{n}=28)$ who reported that $85.7 \%$ of their study of reported anxiety about going on pilgrimage, including $54.1 \%$ who stated they would not complete this act because of their stoma. When counseling Muslims who are anxious about completing pilgrimage, WOC nurse can reassure their patients that the Islam faith provides alternatives for followers who cannot fulfill the pilgrimage requirement. Specifically persons whose health has so deteriorated that they will not be able to go on pilgrimage can appoint a person as an agent to fulfill this religious responsibility. ${ }^{32,33}$

\section{Limitations}

Although the sample was comparatively large, it was drawn from patients managed by a single stoma therapy unit. In addition, it did not evaluate the impact of a urostomy on religious practices. In addition, it is not possible to know the extent the ostomy, as compared to the underlying disease state, and comorbid conditions may have contributed to the challenges associated with practicing their Muslim faith.

\section{Conclusion}

Following ostomy surgery, persons practicing the Islamic faith face multiple challenges related to certain acts of worship. We found that patients increased the frequency of acts of ablution performances, and many altered the frequency and approach to performance of the salat. The presence of a fecal ostomy was also associated with a sharp decline in annual fasting practices and confidence related to pilgrimage. We encourage WOC 
nurses to increase their knowledge of the impact of religion on specific faith-based practices following creation of an ostomy and to provide Muslim patients with specific education about the practice of their religion or identify resources for these persons as they prepare from and recover form, ostomy surgery.

\section{References}

1. Akgün EZ, Yoldaş T. İntestinal stoma. Kolon Rektum Hast Derg. 2012;22: 133-146.

2. Alabaz Ö, Akçam T. İntestinal stomalar. In: Baykan A, Zorluoğu A, Geçim E, Terzi C, ed. Kolon ve Rektum Kanserleri. 1st. edition. İstanbul: Seçil Ofset Matbaacılık ve Ambalaj Sanayi Ltş. Şti; 2010:671-692.

3. International Agency for Research on Cancer. Colorectal Cancer Estimated Incidence, Mortality and Prevalence World wide in 2012. International Agency for Research on Cancer. http://globocan.iarc.fr. Accessed May 242014.

4. Centers of Disease Control and Prevention. Colorectal Cancer Statistics. Centers of Disease Control and Prevention. http://www.cdc.gov/cancer/colorectal/statistics/. Accessed May 242014.

5. Sağlık Araştırmaları Genel Müdürlüğü. Sağlık İstatistikleri Yıllığı 2012. http://www.sagem.gov.tr/dosyalar/saglik_istatistikleri_2012.pdf. Accessed May 242014.

6. Colostomy association. http://www.colostomyassociation.org.uk/. Accessed September 2013.

7. Karabulut HK, Dinç L, Karadağ A. Effects of planned group interactions on the social adaptation of individuals with an intestinal stoma: a quantitative study. J Clin Nurs. 2014; 23(19-20):2800-13. doi: 10.1111/jocn.12541. 
8. 8. Ayaz S. Stomalı bireylerde hemşirenin rolü. Turkiye Klinikleri J Med Sci. 2007;27, 8690.

9. Beitz JM, Colwell JC. Stomal and peristomal complications: prioritizing management approaches in adults. J Wound Ostomy Continence Nurs. 2014;41(5):445-54. doi: 10.1097/WON.0000000000000052.

10. Kuzu MA, Topçu Ö, Uçar $\mathrm{K}$ et al. Effect of sphincter-sacrificing surgery for rectal carcinoma on quality of life in Muslim patients. Dis Colon Rectum. 2002;45, 1359-1366.

11. Karadağ A, Öztürk D, Çelik B. Ostomili bireylere yönelik yaşam kalitesi ölçeğinin Türkçeye uyarlanması. Kolon Rektum Hast Derg. 2011; 21, 173-181.

12. Herek Y, Akbaş M, Taylan S, Alabaz Ö. Stomanın ibadet üzerine etkisi. Ostomi Dergisi. 2003;1, 22- 24.

13. Celasin H, Karakoyun R, Y1lmaz S et al. Quality of life measures in Islamic rectal carcinoma patients receiving counselling. Colorectal Dis. 2011;13, 170-175.

14. Şentürk L, Yazıcı S. İslam ilmihali. Ankara, Diyanet İşleri Başkanlığı Yayınları; 2003.

15. Karaman H. İslamın ışığında günün meseleleri 2. İstanbul, Marifet Yayınları; 1982.

16. Karadağ A, Menteş B, Ayaz S, İrkörücü O, Alabaz Ö. Kolostomili ve ileostomili hastaların bakımına yönelik rehber kitap. Ankara, Ayhun Ofset; 2003.

17. Çavdar İ, Özbaş A, Akyuz N, Fındık U, Kutlu Y. Religious worship in patients with abdominal stoma: praying and fasting during Ramadan. International Journal of Caring Sciences. 2013;6(3):516-521.

18. Tarı Ö. Abdomainal stomalı hastalarda yaşam kalitesinin incelenmesi. Yüksek Lisans Tezi. İstanbul Üniversitesi Sağlık Bilimleri Enstitüsü. İstanbul, 2011. 
19. Karadağ A, Baykara Z. Colostomy irrigation: an importantissue for Muslim individuals. Asian Pacific J Cancer Prev. 2009;10, 1189-1190.

20. Khan MA, Jamal, S, Rashid R, Ahmad N. Quality of life assessment in patients with stoma in Muslim population. Ann Pak. Inst. Med. Sci. 2011;7, 222-227.

21. Duruk, N. Hemşirelerin intestinal stoma bakımına ilişkin bilgileri. Yüksek Lisans Tezi. Hacettepe Üniversitesi Sağlık Bilimleri Enstitüsü. Ankara, 2007.

22. Hussein MA, Fadl SA. Quality of life in Egyptian stoma patients. Egyptian Journal of Surgery. 2001;20, 597-607.

23. Costantini A, Navarra CM, Ashing-Giva T, Yeung S. Sexuality and gender: psychosocial implications in cancer patients: a multicultural perspective. In: Grassiand L, Riba M, ed. Clinical Psycho-Oncology An International Perspective. 1st edition. Wiley; 2012:39-54.

24. Türk Dil Kurumu. Hac. Türk Dil Kurumu. http://www.tdk.gov.tr/index.php. Accessed August 132014.

25. Çiçekler M. Allah’ın Varlığı ve Birliği. İstanbul, Mas Matbaacılık; 2009.

26. Karadoğu A. Sosyo-kültürel açıdan namaz ibadeti. Yüksek Lisans Tezi. Selçuk Üniversitesi Sosyal Bilimler Enstitüsü. Konya, 2008.

27. Tüzer H. Abdominal stomalı hastaların stoma bakımına ilişkin bilgi düzeylerinin belirlenmesi. Yükesk Lisans Tezi. Gazi Üniversitesi Sağlık Bilimleri Enstitüsü. Ankara, 2007.

28. Mutlu S. Kalıcı abdominal stomalı hastalarda beden imajı değişiminin yaşam kalitesine etkisi. Yüksek Lisans Tezi. Marmara Üniversitesi Sağlık Bilimleri Enstitüsü. İstanbul, 2006. 
29. Yaşan A, Ünal S, Gedik E, Girgin S. Kalıcı ve geçici ostomi yapılmış kişilerde yaşam kalitesinde değişim, depresyon ve anksiyete. Anadolu Psikiyatri Dergisi. 2008;9:162-168.

30. Diyanet İşleri Başkanlığı. Özürlünün Abdesti. Diyanet İşleri Başkanlığı. http://www.diyanet.gov.tr/dijitalyayin/ilmihal_cilt_1.pdf. . Accessed August 152012.

31. Altuntaş YE, Gezen FC, Sahoniz $\mathrm{T}$ et al. Ramadan fasting in patients with a stoma: a prospective study of quality of life and nutritional status. Ostomy/Wound Management. 2013; 59(5):26-32.

32. Diyanet İşleri Başkanlığı. Haccın Tanımı ve Mahiyet. Diyanet İşleri Başkanlığı. http://www.diyanet.gov.tr/dijitalyayin/ilmihal_cilt_1.pdf. Accessed December 202013.

33. Karagöz İ, Keskin M, Altuntaş H. Hac İlmihali. $10^{\text {th }}$ ed. Ankara: Diyanet İşleri Başkanlığ1 Yayınları;

2013.http://www2.diyanet.gov.tr/DiniYay\%C4\%B1nlarGenelMudurlugu/WebKutuphanes i/cepkitaplar\%C4\%B1/hac_ilmihali.pdf. Accessed January 42014.

Table1. Demographic Characteristics of the Patients

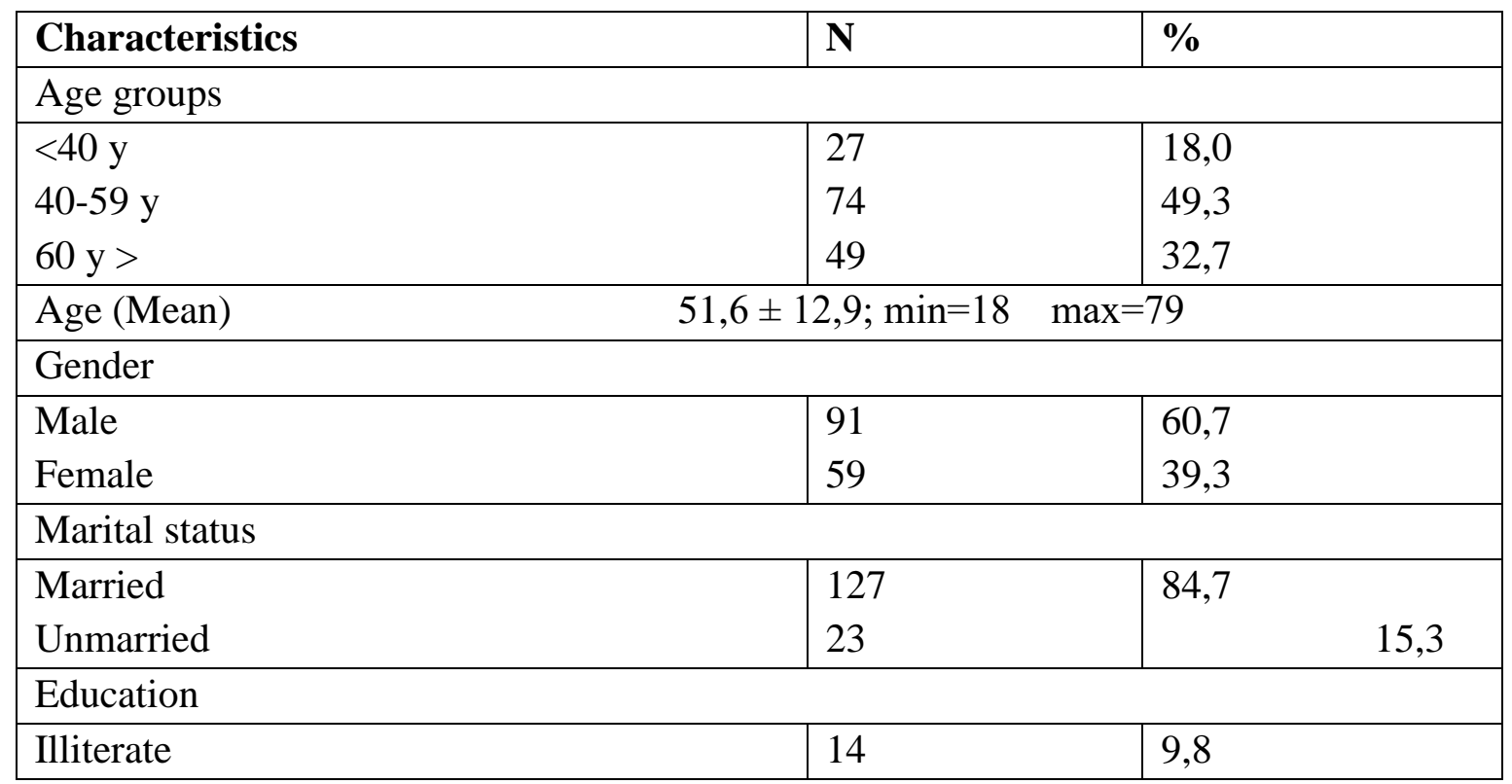




\begin{tabular}{|l|l|l|}
\hline Literate & 5 & 3,2 \\
Primary school & 37 & 24,6 \\
Middle school & 32 & 21,2 \\
High school & 39 & 26,0 \\
University & 23 & 15,2 \\
\hline Occupation & 54 & 36,0 \\
\hline Retired & 49 & 32,7 \\
Homemaker & 17 & 11,3 \\
Office clerk & 13 & 8,7 \\
Unemployed & 17 & 11,3 \\
Other* & \multicolumn{2}{|l|}{} \\
\hline Level of income & 28 & 18,6 \\
\hline Below 739,80t (Very low income) & 55 & 36,7 \\
739,80t - 919,48 (Low income) & 52 & 34,7 \\
$919,48 *$ - 2995040屯 (Middle range incomes) & 15 & 10,0 \\
$2995040 t$ and above (Upper range incomes) & 15 & 41,3 \\
\hline People lived together with & 62 & 46,0 \\
\hline Spouse & 69 & 10,0 \\
Spouse and children & 15 & 2,7 \\
Mother- Father & 4 & 100,0 \\
Alone & 150 & \\
\hline Total & \multicolumn{2}{|l|}{} \\
\hline
\end{tabular}


Table 2. Distribution of Participants' Health Conditions and Stoma Related Features

\begin{tabular}{|c|c|c|}
\hline Characteristics & $\mathbf{n}$ & $\%$ \\
\hline \multicolumn{3}{|c|}{ Medical diagnosis leading to ostomy surgery $(\mathrm{n}=150)$} \\
\hline Rectum Ca & 70 & 46,7 \\
\hline Ulcerative colitis & 29 & 19,3 \\
\hline Crohn Disease & 20 & 13,3 \\
\hline Colon $\mathrm{Ca}$ & 16 & 10,7 \\
\hline FAP & 9 & 6,0 \\
\hline Other* & 6 & 4,0 \\
\hline \multicolumn{3}{|c|}{ Stoma type $(n=150)$} \\
\hline Colostomy & 61 & 40,7 \\
\hline Ileostomy & 89 & 59,3 \\
\hline \multicolumn{3}{|c|}{ Time since ostomy surgery (months) } \\
\hline \multicolumn{3}{|c|}{ Mean $14.71 \pm 16.7$ months } \\
\hline 3-12 months & 98 & 65,3 \\
\hline 13-24 months & 34 & 22,7 \\
\hline$>24$ months & 18 & 12,0 \\
\hline \multicolumn{3}{|c|}{ Received education about worship practices after surgery } \\
\hline Yes & 92 & 61,3 \\
\hline No & 58 & 38,7 \\
\hline \multicolumn{3}{|c|}{ Who provided education $(\mathrm{n}=92)$} \\
\hline WOC Nurse & 87 & 94,5 \\
\hline Physician & 4 & 4,5 \\
\hline Clergyman & 1 & 1,0 \\
\hline \multicolumn{3}{|c|}{ Satisfaction with education $(n=92)$} \\
\hline Satisfied & 81 & 88,0 \\
\hline Unsatisfied & 11 & 12,0 \\
\hline
\end{tabular}


Table 3. Performance of Salat Following Ostomy Surgery

\begin{tabular}{|c|c|c|}
\hline Salat performance conditions & $\mathbf{n}$ & $\%$ \\
\hline \multicolumn{3}{|l|}{ Daily salat $(\mathrm{n}=150)$} \\
\hline Does not perform at all & 30 & 20,0 \\
\hline No change in number of salat, but done at home & 55 & 36,0 \\
\hline $\begin{array}{l}\text { No change in number of salat, and done in the } \\
\text { mosque }\end{array}$ & 2 & 1,3 \\
\hline Increase in number of salat, done at home & 6 & 4,0 \\
\hline Decrease in number of salat, done at home & 34 & 22,7 \\
\hline Stopped the salat completely & 20 & 14,0 \\
\hline Started the salat at home & 3 & 2,0 \\
\hline \multicolumn{3}{|l|}{ Friday Prayer at the mosque $(\mathrm{n}=91)$} \\
\hline No change in Friday prayers, did not go before & 11 & 12,0 \\
\hline No change in Friday prayer, continued regularly & 46 & 50,8 \\
\hline Decreased attendance in Friday prayer & 23 & 25,2 \\
\hline Stopped Friday prayer attendance & 11 & 12,0 \\
\hline \multicolumn{3}{|l|}{ Funeral Salat $(\mathrm{n}=150)$} \\
\hline No change, never attended before & 60 & 40,0 \\
\hline No change in attendance, joined in regularly & 55 & 36,7 \\
\hline Increase in attendance to funeral salats & 2 & 1,3 \\
\hline Decrease in funeral salats & 21 & 14,0 \\
\hline Stopped attending funeral salats & 12 & 8,0 \\
\hline \multicolumn{3}{|l|}{ Salat-al Witr (n=150) } \\
\hline No change, done at home & 55 & 36,7 \\
\hline No change, never performed this salat & 31 & 20,7 \\
\hline No change, performed in the mosque & 2 & 1,3 \\
\hline Decrease in performance, done at home & 32 & 21,3 \\
\hline Increase in performance, done at home & 6 & 4,0 \\
\hline Stopped performing this salat & 20 & 13,3 \\
\hline Started this salat at home & 4 & 2,7 \\
\hline
\end{tabular}




\begin{tabular}{|c|c|c|}
\hline \multicolumn{3}{|l|}{ Eid salat $(\mathrm{n}=150)$} \\
\hline No change, performed at home & 11 & 7,3 \\
\hline No change, performed in the mosque & 46 & 30,6 \\
\hline No change, never performed this salat & 47 & 31,3 \\
\hline Increase in performance, at home & 1 & 0,7 \\
\hline Increase in performance, in the mosque & 2 & 1,3 \\
\hline Decrease in performance, at home & 4 & 2,7 \\
\hline Decrease in performance, in the mosque & 22 & 14,7 \\
\hline Stopped performing this salat & 16 & 10,7 \\
\hline Started this salat, performed at home & 1 & 0,7 \\
\hline \multicolumn{3}{|l|}{ Nafil salat $(n=150)$} \\
\hline No change, performed at home & 50 & 33,3 \\
\hline No change, performed in the mosque & 2 & 1,3 \\
\hline No change, never performed this salat & 36 & 24,0 \\
\hline Increase in performance, at home & 6 & 4,0 \\
\hline Decrease in performance, at home & 30 & 200 \\
\hline Decrease in performance, in the mosque & 1 & 0,7 \\
\hline Stopped performing this salat & 21 & 14,0 \\
\hline Started this salat, performed at home & 4 & 2,7 \\
\hline \multicolumn{3}{|c|}{ Does discharge of gas or feces invalidate the salat? $(n=114)$} \\
\hline $\begin{array}{l}\text { Does not invalidate } \\
\text { Invalidates }\end{array}$ & $\begin{array}{l}90 \\
24\end{array}$ & $\begin{array}{l}78,9 \\
21,1\end{array}$ \\
\hline
\end{tabular}


Table 4. Distribution of Patients' Ablution Related Acts after Ostomy Surgery

\begin{tabular}{|c|c|c|}
\hline Ablution Performance Related Features & $\mathbf{n}$ & $\%$ \\
\hline \multicolumn{3}{|l|}{ Change in ablution frequency $(\mathrm{n}=150)$} \\
\hline Increased & 72 & 48,0 \\
\hline No change & 42 & 28,0 \\
\hline No answer & 36 & 24,0 \\
\hline \multicolumn{3}{|c|}{ Number of ablutions performed before each salat $(\mathrm{n}=72)$} \\
\hline 1 & 67 & 93,0 \\
\hline 2 & 3 & 4,3 \\
\hline 3 & 2 & 2,7 \\
\hline \multicolumn{3}{|c|}{ Feeling clean enough before starting the salat $(\mathrm{n}=150)$} \\
\hline Feels clean & 84 & 56,0 \\
\hline Does not feel clean & 31 & 20,7 \\
\hline No answer & 35 & 23,3 \\
\hline \multicolumn{3}{|c|}{$\begin{array}{l}\text { Believes that discharge of gas or feces into the bag after ablution invalidates the ablution } \\
(\mathrm{n}=150)\end{array}$} \\
\hline No & 83 & 55,3 \\
\hline Yes & 32 & 21,3 \\
\hline No answer & 35 & 23,4 \\
\hline
\end{tabular}


Table 5. Fasting and Pilgrimage Related Activities after Ostomy Surgery

\begin{tabular}{|c|c|c|}
\hline Characteristics & $\mathbf{n}$ & $\%$ \\
\hline \multicolumn{3}{|l|}{ Fast conditions before ostomization $(n=150)$} \\
\hline $\begin{array}{l}\text { Fasted annually and regularly } \\
\text { Never fasted } \\
\text { Irregular fasting }\end{array}$ & $\begin{array}{l}114 \\
30 \\
6\end{array}$ & $\begin{array}{l}76,0 \\
20,0 \\
4,0\end{array}$ \\
\hline \multicolumn{3}{|l|}{ Fast conditions after ostomization $(n=150)$} \\
\hline $\begin{array}{l}\text { Fasted annually and regularly } \\
\text { Never fasted } \\
\text { Irregular fasting }\end{array}$ & $\begin{array}{l}12 \\
129 \\
9 \\
\end{array}$ & $\begin{array}{l}8,0 \\
86,0 \\
6,0\end{array}$ \\
\hline \multicolumn{3}{|c|}{ Beliefs related to the stoma (not) forming an obstacle to pilgrimage $(n=150)$} \\
\hline $\begin{array}{l}\text { Is an obstacle } \\
\text { Is not an obstacle }\end{array}$ & $\begin{array}{l}41 \\
109\end{array}$ & $\begin{array}{l}27,3 \\
72,7\end{array}$ \\
\hline \multicolumn{3}{|l|}{ Reasons for the stoma being perceived as obstacle $(n=41)$} \\
\hline $\begin{array}{l}\text { Those who believe performing ablution for each salat will be } \\
\text { difficult }\end{array}$ & 15 & 36,5 \\
\hline $\begin{array}{l}\text { Those who think that it will be difficult because they worry that } \\
\text { the bag will loosen or open during worship } \\
\text { Those who believe that during pilgrimage it will be necessary to } \\
\text { frequently change/clean the bag, which they think they will find } \\
\text { difficult }\end{array}$ & 14 & 34,1 \\
\hline Those who feel concerned about crowding & 3 & 7,5 \\
\hline
\end{tabular}

\section{Glossary}

Shahada: The first pillar of being a Muslim is having faith in Allah. In order to have faith, it is necessary to recite the Shahada and know the meaning of the same and believe in it.

Ablution (Wudu): The word "abdest", which means ablution in Turkish, is formed by the Persian words âb (water) and dest (hand), and means "hand water". It is a prerequisite for certain prayers and act of cleansing regarded as a prayer, as well. The Islamic law defines ablution as "washing some body parts duly with water and wiping over some other parts with hands wet with water."

Tayammum: In religious literature, tayammum means cleaning by wiping hands, face and both arms with clean sand or a material regarded as a form of earth in the cases where it is not possible to supply or use water. While ablution and ghusl are material cleaning rituals 
performed with water, tayammum is a symbolic act substituting ablution and ghusl in exceptional cases.

Salat: Salat is serving to the almighty Allah with certain acts and special elements. Although external view of salat contains several different postures and invocations, its spirit and real nature is to praise the almighty Allah, speak and get closer to Allah and observe Allah. Salat is a fard prayer for all Muslims including women and men and performed in five different time frames per day.

Fard Salats: Fard salats include the five daily prayers (fajr, dhuhr, asr, maghrib, and isha) and Jumu'ah performed on every Friday.

Daily Prayer: It means the prayer performed in five separate time frames per day.

Jumu'ah: It is the prayer performed gregariously in the mosque on every Friday at noon time.

Salat-al Witr: Witr means "odd", the opposite of "even" in Arabic. The Prophet recommended and incited to perform the last salat of the day in an odd (vitr) number and proposed a time frame close to the fajr and indicated that the Muslims who doubt waking up in the midnight can perform the prayer before they sleep.

Eid Salat: These are the prayers which are performed twice a year at eid al-fitr and eid aladha.

Nafl Salat: It means additional and supererogatory prayer performed to acquire more merit.

Salat al-Janazah: It is the prayer made for deceased Muslims.

Fasting: It means avoiding from eating, drinking and sexual intercourse from fajr (dawn) until maghrib (sunset) for a reason and consciously.

Zakat (Giving Alms): It means allocation of a certain share from the possessions of Muslims who are regarded as rich according to the criteria of Islam. The allocated properties are used for certain purposes for Allah's sake.

Haj (Pilgrimage): It means visiting Kaaba in Mecca and holy places around in a certain frame of time, in accordance with Islamic rules and perform other necessary obligations.

References For Glossary: Presidency of Religious Affairs, Ilmihal I: Iman ve Ibadetler Retrieved from: http://www.diyanet.gov.tr/dijitalyayin/ilmihal_cilt_1.pdf; 7 July, 2015 